\title{
Oxidation Behavior of Molybdenum Silicides and Their Composites
}

\author{
K. Natesan \\ Energy Technology Division, Argonne National Laboratory, Argonne, IL 60439, USA \\ and \\ S. C. Deevi \\ Research and Development Center, Philip Morris USA, Richmond, VA 23234
}

February 2000

\begin{abstract}
The submitted manuscript has been created by the University of Chicago as Operator of Argonne National Laboratory ("Argonne") under Contract No. W-31-109-ENG-38 with

the U.S. Department of Energy. The U.S.

Government retains for itself, and others acting on its behalf, a paid-up, nonexclusive, irrevocable worldwide license in said article to reproduce, prepare derivative works, distribute copies to the public, and perform publicly and display publicly, by or on behalf of the Government.
\end{abstract}

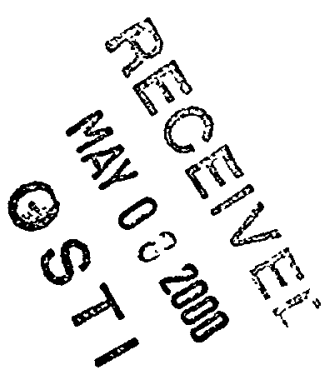

Invited paper presented at the International Symposium on Intermetallics for the Third Millennium, ASM Materials Solutions, Cincinnati, November 1-4, 1999.

*Work supported by the U.S. Department of Energy, Office of Fossil Energy, Advanced Research and Special Technologies Materials Program and Office of Energy Research, Basic Energy Sciences, Division of Materials, under Contract W-31-109-Eng-38. 


\section{DISCLAIMER}

This report was prepared as an account of work sponsored by an agency of the United States Government. Neither the United States Government nor any agency thereof, nor any of their employees, make any warranty, express or implied, or assumes any legal liability or responsibility for the accuracy, completeness, or usefulness of any information, apparatus, product, or process disclosed, or represents that its use would not infringe privately owned rights. Reference herein to any specific commercial product, process, or service by trade name, trademark, manufacturer, or otherwise does not necessarily constitute or imply its endorsement, recommendation, or favoring by the United States Government or any agency thereof. The views and opinions of authors expressed herein do not necessarily state or reflect those of the United States Government or any agency thereof. 


\section{DISCLAIMER}

Portions of this document may be illegible in electronic image products. Images are produced from the best available original document. 


\title{
Oxidation Behavior of Molybdenum Silicides and Their Composites
}

\author{
K. Natesan
}

Energy Technology Division, Argonne National Laboratory, Argonne, IL 60439, USA

and

S. C. Deevi

Research and Development Center, Philip Morris USA, Richmond, VA 23234

\begin{abstract}
A key materials issue associated with the future of high-temperature structural silicides is the resistance of these materials to oxidation at low temperatures. Oxidation tests were conducted on Mo-based silicides over a wide temperature range to evaluate the effects of alloy composition and temperature on the protective scaling characteristics and pesting regime for the materials. The study included $\mathrm{Mo}_{5} \mathrm{Si}_{3}$ alloys that contained several concentrations of $\mathrm{B}$. In addition, oxidation characteristics of $\mathrm{MoSi}_{2}-\mathrm{Si}_{3} \mathrm{~N}_{4}$ composites that contained $20-80$ vol. $\% \mathrm{Si}_{3} \mathrm{~N}_{4}$ were evaluated at $500-1400^{\circ} \mathrm{C}$.
\end{abstract}

Key words: molybdenum silicide, oxidation, boron addition, silicon nitride, composites, thermodynamics, kinetics

\section{INTRODUCTION}

High-temperature structural materials are critically needed for the improvement of the thermal efficiency and reliability of energy conversion systems and advanced engine systems. Currently available alloys, such as Ni-based single-crystal superalloys, are limited to use at temperatures of $\approx 1100^{\circ} \mathrm{C}$. Superalloys derive their intrinsic strength from reinforcements of gamma prime precipitates, but they tend to coarsen and ultimately dissolve as the temperature increases beyond $1100^{\circ} \mathrm{C}$. NiAl-based aluminide alloys, which are currently under development, have the potential for use at temperatures up to $1200^{\circ} \mathrm{C}$. However, many applications require temperature capabilities that exceed this temperature by at least $200^{\circ} \mathrm{C}$. The melting temperature $\left(\mathrm{T}_{\mathrm{m}}\right.$ ) of a material for structural applications at $1400^{\circ} \mathrm{C}$ should be $>2000^{\circ} \mathrm{C}$ so that, at most, 0.75 $\mathrm{T}_{\mathrm{m}}$ is reached during service, and appreciable high-temperature strength is maintained. Of the potential candidate systems, Mo silicides are particularly attractive owing to their high melting points. Molybdenum disilicide exhibits particularly good mechanical strength properties [1-3], high thermal conductivity, high electrical conductivity [4] and promising oxidation resistance at elevated temperature [5-8]. However, the material has been reported to exhibit high creep rates at temperatures $>1200^{\circ} \mathrm{C}$ [9] and degradation by a phenomenon known as "pesting" in the 
temperature range of $400-600^{\circ} \mathrm{C}$ [10-13]. This paper will address the issues of oxidation of Mo silicides, in particular $\mathrm{Mo}_{5} \mathrm{Si}_{3}$-based materials, and $\mathrm{MoSi}_{2}-\mathrm{Si}_{3} \mathrm{~N}_{4}$ composites, with emphasis on oxidation performance at low temperatures.

\section{BACKGROUND}

Oxidation of Mo silicides strongly depends on the exposure temperature. Accelerated oxidation at low temperatures is generic to all forms and compositions of Mo silicides. Three regimes are present in the oxidation of these materials. These are protective scaling, nonprotective scaling, and accelerated oxidation or "pesting." Pesting is the result of the occurrence of accelerated oxidation within microcracks, accompanied by a large volume increase; the result of such reactions is that the material is transformed into powder. Grain boundaries alone do not lead to pesting because dense hipped $\mathrm{MoSi}_{2}$ did not pest even though it was polycrystalline; also, single-crystal $\mathrm{Mo}_{5} \mathrm{Si}_{3}$ does pest. Fabrication method may not have a dominant effect on pesting in as much as materials made by both conventional melting/casting and powder metallurgy routes pest. Because $\mathrm{MoSi}_{2}$ is a stoichiometric compound, the fabricated material normally contains excess Si or Mo. The composition, microstructure, and density of the starting material seem to have a large influence on the oxidation performance of these alloys. .

The oxidation behavior of Mo silicide alloys is predominantly dictated by exposure conditions, which in turn determine the relative growth rates of silica and Mo oxide. At high temperatures $\left(>1000^{\circ} \mathrm{C}\right), \mathrm{SiO}_{2}$ scale forms and seals the surface and the alloy exhibits protective scaling. At intermediate temperatures, $\mathrm{SiO}_{2}$ forms slowly and generally does not fully seal the surface or the grains of silicide and Mo oxide has a tendency to form continuously and volatilize. Under such conditions, the alloy may not develop a protective silica scale and may exhibit nonprotective scaling. At low temperatures, $\mathrm{SiO}_{2}$ does not form fast enough to provide protection, and the oxidation process is dominated by formation of volatile Mo oxide. Although oxidation to form $\mathrm{SiO}_{2}$ on the surface of the alloy is beneficial, if it occurs in the interior of the sample, the alloy may be subjected to pesting attack because of a large increase in volume of 340 and $180 \%$ respectively, when $\mathrm{MoO}_{3}$ is formed from $\mathrm{Mo}$ and $\mathrm{SiO}_{2}$ is formed from Si. Porosity and preexisting cracks in the starting material have a large influence on oxidation performance in that the oxidation in the interior of the alloy can lead to widening of the cracks and enlargement of the pores and thus further accelerate the oxidation reaction.

Several studies have been conducted to achieve protective oxidation of Mo silicides by addition of a third element such as $\mathrm{Al}, \mathrm{Ta}, \mathrm{Ti}, \mathrm{Zr}$, or $\mathrm{Y}$ [14-17]. All of these additives form oxides that are more stable than $\mathrm{SiO}_{2}$ and it is thought that the effect of their scavenging for $\mathrm{O}$ may accelerate the scaling process and thereby prevent or minimize Mo oxide formation. The 
addition of these elements, $\mathrm{Al}$ in particular, reportedly reduces pesting by formation of an amorphous Mo-Si-Al-O phase in the initial cracks and voids [17]. However, the growth rates for the oxides of any of these third-element additions (at low concentration) are fairly low and comparable to that of $\mathrm{SiO}_{2}$ and may not fully minimize pesting attack at low temperatures.

An alternate approach is to add elements such as B to change the composition of the scale from silica to borosilicate, whose plasticity/fluidity is supposed to encapsulate the silicide grains (i.e., along the grain boundaries) and eliminate pesting of the alloy [18]. The improved oxidation resistance of $\mathrm{B}$-doped $\mathrm{Mo}_{5} \mathrm{Si}_{3}$ at $800^{\circ} \mathrm{C}$ is attributed to the mechanism of viscous sintering of the scale to close'pores that form during the initial transient oxidation period because of the volatilization of Mo oxide. However, the study was not extended to lower temperatures where the pesting is a real problem in any of the Mo silicide alloys.

\section{EXPERIMENTAL PROGRAM}

The objectives of this program are to experimentally evaluate the oxidation behavior of Mo silicide, in particular $\mathrm{Mo}_{5} \mathrm{Si}_{3}$-based alloys, in air at temperatures in a range of $500-1400^{\circ} \mathrm{C}$ and characterize the microstructure, composition, and phase stability in the oxidized condition. The alloys included $\mathrm{B}$ additions, and the alloy fabrication procedure included hot pressing and casting/solidification routes. Furthermore, the oxidation performance of selected compositions of $\mathrm{MoSi}_{2}-\mathrm{Si}_{3} \mathrm{~N}_{4}$ composites was evaluated over a wide temperature range and the oxidation morphologies were characterized. Figure 1 is a schematic illustration of the Mo-Si-B ternary phase diagram, in which the binary silicide phases are of the composition $\mathrm{MoSi}_{2}, \mathrm{Mo}_{5} \mathrm{Si}_{3}$ ( $\mathrm{T} 1$ phase), and $\mathrm{Mo}_{3} \mathrm{Si}$. Additions of $\mathrm{B}$ to the alloy can lead to a $\mathrm{T} 2$ phase of composition $\mathrm{Mo}_{5} \mathrm{SiB}_{2}$. It is also evident that among the three binary silicides, $\mathrm{B}$ is somewhat soluble only in $\mathrm{Mo}_{5} \mathrm{Si}_{3}$ (may be up to $\approx 3$ at.\%), whereas $\mathrm{MoSi}_{2}$ and $\mathrm{Mo}_{3} \mathrm{Si}$ are essentially stoichiometric compounds. The diagram also indicates that additions of $\mathrm{B}$ to $\mathrm{MoSi}_{2}$ can lead to stable three-phase regions comprising $\mathrm{MoB}_{2}+\mathrm{Si}+\mathrm{MoSi}_{2}$ or $\mathrm{MoB}+\mathrm{MoSi}_{2}+\mathrm{Mo}_{5} \mathrm{Si}_{3}$, depending on whether or not the alloy contains excess Si. Similarly, addition of $>3$ at. $\%$ B can lead to $\mathrm{MoB}+\mathrm{MoSi}_{2}+\mathrm{T} 1$ or $\mathrm{Mo}_{3} \mathrm{Si}+\mathrm{T} 1+\mathrm{T} 2$ phases. The oxidation performance of the alloy can be influenced by the phases present in the starting material and the amount of free Si and/or Mo in the alloy.

Several materials were used in the present study to examine the importance of variables such as fabrication method, B content, phase composition, grain structure, and composite composition on the oxidation process. Table 1 lists the alloys used in the experiments, together with the method of fabrication and source of the alloy. The $\mathrm{Mo}_{5} \mathrm{Si}_{3}$ alloy produced at Argonne National Laboratory (ANL) by hot pressing the powder of the same composition exhibited a polycrystalline structure, whereas the alloy of the same composition produced at Los Alamos 
National Laboratory (LANL) was a single crystal. In addition, T1 phase with 2 at.\% B, which would be a single phase, was used to evaluate the influence of $B$ in solid solution on oxidation. The LANL T2 alloy is a cast material with a matrix composition of $\mathrm{Mo}_{5} \mathrm{SiB}_{2}$ and some small amount of a second phase; this alloy contained 25 at.\% B, based on the stoichiometry of the matrix phase.

B-doped $\mathrm{Mo}_{5} \mathrm{Si}_{3}$, obtained from Ames Laboratory, was synthesized by. arc melting Mo, $\mathrm{Si}$, and $\mathrm{B}$ in a consumableW arc-melt furnace under an $\mathrm{Ar}$ atmosphere. Addition of 9.3 at.\% (1.87 wt.\%) B produced a three-phase mixture of $\mathrm{Mos}_{5} \mathrm{Si}_{3}, \mathrm{MoB}$, and $\mathrm{MoSi}_{2}$. The arc-melt buttons were ground to submicrometer size powders and dry pressed into bars at $46 \mathrm{MPa}$. The bars were then hipped at $1440^{\circ} \mathrm{C}$ and $210 \mathrm{MPa}$ for $4 \mathrm{~h}$ to produce the final alloy. The Oak Ridge National Laboratory (ORNL) alloy MSB1 was made by hot pressing $\mathrm{MoSi}_{2}, \mathrm{Mo}, \mathrm{B}$, and C powders at $1600^{\circ} \mathrm{C}$, whereas Alloy $\# 425$ was made by melting and casting in a sand mold and slow solidification. The $\mathrm{MoSi}_{2}-\mathrm{Si}_{3} \mathrm{~N}_{4}$ composites of several compositions were fabricated by hot pressing powders of the two materials with sintering aids.

Oxidation of the alloys was conducted in a thermogravimetric apparatus (TGA), in which sensitivity of the electrobalance was $0.1 \mu \mathrm{g}$. Specimens were suspended from the balance in. a vertical furnace and held for the desired exposure period. All of the oxidation experiments were conducted in high-purity air, exposure temperatures ranged between 500 and $1200^{\circ} \mathrm{C}$, and exposure times were up to $200 \mathrm{~h}$. Upon completion of the oxidation test, the furnace was opened and the specimens were rapidly cooled to room temperature. Following thermogravimetric measurement of oxidation, scale surfaces and/or cross sections of specimens were examined with a scanning electron microscope (SEM) equipped with an energy-dispersive X-ray (EDX) analyzer, and X-ray diffraction (XRD).

Oxidation experiments on composites were conducted in an apparatus in which specimens of various compositions were exposed simultaneously to flowing high-purity air. Specimens were periodically retrieved, weighed, and measured. The exposure temperatures for oxidation of composite specimens ranged between 500 and $1400^{\circ} \mathrm{C}$ and exposure times were up to $1800 \mathrm{~h}$. Upon completion of exposures, specimen surfaces and cross sections were characterized by SEM and EDX.

\section{RESULTS}

Oxidation of $\mathrm{Mo}_{5} \mathrm{Si}_{3}$

Specimens of ANL-made binary silicide were oxidized in a TGA at $600,700,800$, and $1000^{\circ} \mathrm{C}$ in high-purity air. Figure 2 shows the weight change data for specimens oxidized at several temperatures. The specimen tested at $600^{\circ} \mathrm{C}$ showed some weight gain and the sample 
surface exhibited white powder after oxidation. XRD analysis indicated $\mathrm{MoO}_{3}$ as the predominant phase. The specimen tested at $700^{\circ} \mathrm{C}$ exhibited an almost linear weight loss rate $\left(0.011 \mathrm{mg} / \mathrm{cm}^{2} \cdot \mathrm{h}\right)$ and the sample surface was white. The sample disintegrated into powder, indicating degradation by the pesting phenomenon. At $800^{\circ} \mathrm{C}$, the specimen exhibited a substantial weight loss at a linear rate of $6.6 \mathrm{mg} / \mathrm{cm}^{2} \cdot \mathrm{h}$. XRD results of the oxidized specimen showed $\mathrm{Mo}_{5} \mathrm{Si}_{3}$ and $\mathrm{Mo}_{3} \mathrm{Si}$ phases. The $\mathrm{MoO}_{3}$ phase volatilized and was deposited at lowtemperature locations within the reaction chamber and on the suspension wire, as shown in the macrophotograph in Fig. 3. The presence of $\mathrm{Mo}_{3} \mathrm{Si}$ indicates that two competing reactions are prevalent:

$$
2 \mathrm{Mo}_{5} \mathrm{Si}_{3}+21 \mathrm{O}_{2}=10 \mathrm{MoO}_{3} \text { (volatile) }+6 \mathrm{SiO}_{2}
$$

and

$$
3 \mathrm{Mo}_{5} \mathrm{Si}_{3}+4 \mathrm{O}_{2}=5 \mathrm{Mo}_{3} \mathrm{Si}+4 \mathrm{SiO}_{2}
$$

However, the $\mathrm{SiO}_{2}$ phase does not form fast enough to completely cover the $\mathrm{Mo}_{5} \mathrm{Si}_{3} / \mathrm{Mo}_{3} \mathrm{Si}$ grains to offer protection against further oxidation. The specimen that was oxidized at $1000^{\circ} \mathrm{C}$ exhibited almost no weight change for $\approx 40 \mathrm{~h}$, after which it started to lose weight. XRD analysis of the specimen surface showed $\mathrm{Mo}_{5} \mathrm{Si}_{3}, \mathrm{Mo}_{3} \mathrm{Si}$, and $\mathrm{SiO}_{2}$ while significant volatilization of Mo oxides had occurred. We believe that the slow growth rate of $\mathrm{SiO}_{2}$ scale is not able to completely protect the alloy, even at $1000^{\circ} \mathrm{C}$.

Oxidation of B-containing $\mathrm{Mo}_{5} \mathrm{Si}_{3}$

Table 1 lists the composition, fabrication method, and source of the B-containing $\mathrm{Mo}_{5} \mathrm{Si}_{3}$ alloys, that were used in the oxidation study. Figure $4 \mathrm{~A}$ shows the thermogravimetric weight change data for several of the alloys after exposure in air at $800^{\circ} \mathrm{C}$. The single-crystal alloy (LANL/SC) and the T1-phase alloy (LANL/T1) that contained 2 at.\% B exhibited rapid weight loss, indicating the formation of volatile Mo oxide and no protection from silica. Figure 4B is a replot of the same data used in Fig. 4A, but without the data for the single-crystal and $\mathrm{T} 1$ alloys. The B-containing alloys generally exhibit a protective scaling behavior whereas the $\mathrm{Mo}_{5} \mathrm{Si}_{3}$ without $B$ shows continued weight loss even at this temperature. However, the alloy does not pest or turn into powder but only undergoes nonprotective scaling. The results also indicate that the MSB1 alloy, with 7.3 at.\% B, exhibited gradual weight loss and never reached a plateau (like the other two B-containing alloys). This is probably due to the presence in the alloy of free $\mathrm{Mo}$, which can arise because the alloy was made by hot pressing powders of $\mathrm{MoSi}_{2}, \mathrm{Mo}, \mathrm{B}$, and $\mathrm{C}$. The oxidation behavior of the LANL alloy that contained predominantly T2 phase $(\approx 25$ at. $\%$ B $)$ was similar to that of the Ames alloy when exposed in air at $800^{\circ} \mathrm{C}$. Figure 5 shows the XRD patterns for the Ames and LANL alloys after oxidation. The predominant phase in the oxidation 
product in both alloys is $\mathrm{MoO}_{2}$. The higher $\mathrm{B}$ content may favor formation of amorphous silica or borosilicate, which can be inferred from the larger hump in the diffraction pattern (at 2-theta angles in the range of $10-20^{\circ}$ ) for the LANL alloy.

Because the Ames alloy, which contained 9.3 at.\% B, exhibited protective scaling after an initially rapid weight loss for a short period of time, we elected to further evaluate its oxidation behavior over the wide temperature range of $500-1200^{\circ} \mathrm{C}$. Figure 6 shows the thermogravimetric weight change data for this alloy when oxidized in air at $500,600,700$, and $800^{\circ} \mathrm{C}$. The tests at 600 and $700^{\circ} \mathrm{C}$ were repeated to validate reproducibility of the results. The data showed a protective scaling of the alloy at $500^{\circ} \mathrm{C}$, not because of $\mathrm{SiO}_{2}$ formation, but because the rate of volatilization of Mo oxide is negligible. At $600{ }^{\circ} \mathrm{C}$, the alloy exhibited substantial weight loss after an initial weight increase for $\approx 100 \mathrm{~h}$. When repeated at $600^{\circ} \mathrm{C}$, the test also exhibited weight loss but at a somewhat lower rate. Figure 7 shows SEM secondary- and backscatteredelectron images (SEIs and BEIs) of the alloy after oxidation at $600^{\circ} \mathrm{C}$. The white regions in the BEI were identified by EDX as pure Mo. Because this alloy was made by hipping a three-phase mixture, no free Mo is expected in the starting material; thus, the Mo must have been produced by direct oxidation of $\mathrm{Mo}_{5} \mathrm{Si}_{3}$ to $\mathrm{Mo}$ and $\mathrm{SiO}_{2}$. XRD analysis did not detect any $\mathrm{SiO}_{2}$ or borosilicate phase, but these phases will be amorphous and lack of detection does not mean they are absent.

Oxidation tests conducted at $700^{\circ} \mathrm{C}$ showed a sharp weight loss over a few hours of oxidation and the tests had to be stopped to prevent complete loss of the specimens. To examine this loss further, additional tests were conducted at $700^{\circ} \mathrm{C}$. During these additional tests, several specimens were exposed in air for $0.5,1.5$, and $5 \mathrm{~h}$. Weight change data for these tests are given in Fig. 8, with the three exposure times marked as A, B, and C. XRD analysis was conducted on the three specimens and the diffraction patterns are shown in Fig. 9. It is evident that the dominant phase in all three specimens is $\mathrm{MoO}_{3}$; very little $\mathrm{SiO}_{2}$, if any, is detected. Figure 10 shows the SEM photographs of the three specimens. After $0.5 \mathrm{~h}$ of exposure, the specimen showed needle-like $\mathrm{MoO}_{3}$ phase and after $1.5 \mathrm{~h}$, some consolidation is noted. After $5 \mathrm{~h}$ of exposure, the needle-like morphology has completely disappeared and the white spots on the surface were identified by EDX as pure Mo, indicating direct oxidation of $\mathrm{Mo}_{5} \mathrm{Si}_{3}$ to $\mathrm{Mo}$ and $\mathrm{SiO}_{2}$. The alloy undergoes nonprotective scaling at this temperature and has very little tendency to form either silica or borosilicate as a continuous scale to resist further oxidation.

Figure 11 shows the thermogravimetric weight change data for the Ames alloy after oxidation in air at 800,1000 , and $1200^{\circ} \mathrm{C}$. The curves show a sharp drop in specimen weight for $\approx 2 \mathrm{~h}$ at all temperatures, after which a plateau is reached and the weight changes little during 50$70 \mathrm{~h}$ of additional exposure. The curves indicate a protective scaling in the alloy at these 
temperatures. Figure 12 shows the XRD patterns for the Ames alloy after oxidation in air at the three temperatures. The reaction products that lead to protection are the $\mathrm{MoO}_{2}$ phase at $800^{\circ} \mathrm{C}$ and pure Mo and silica/borosilicate (amorphous nature indicated by the humps in the low 2-theta angle region of the XRD pattern) phases at 1000 and $1200^{\circ} \mathrm{C}$. From this information, we can write the possible oxidation reactions as

$$
\mathrm{Mo}_{5} \mathrm{Si}_{3}+8 \mathrm{O}_{2}=5 \mathrm{MoO}_{2}+3 \mathrm{SiO}_{2}
$$

and

$$
\mathrm{Mo}_{5} \mathrm{Si}_{3}+3 \mathrm{O}_{2}=5 \mathrm{Mo}+3 \mathrm{SiO}_{2} .
$$

Figure 13 shows SEM photomicrographs of the surfaces of the Ames alloy oxidized in air at 800 , 1000 , and $1200^{\circ} \mathrm{C}$. The morphology of the scale observed after oxidation at $800^{\circ} \mathrm{C}$ consisted of light-colored $\mathrm{MoO}_{2}$ phase and dark gray colored Si-rich oxide (see photomicrograph marked $800^{\circ} \mathrm{C}$ in Fig. 13). After oxidation at 1000 and $1200^{\circ} \mathrm{C}$, the surface consisted predominantly of $\mathrm{Si}$-rich oxide and almost pure Mo particles. The surface layer showed significant cracking and peeling and seemed to be highly plastic, as indicated by the curling rather than spalling of the oxide layer. Such a mode of degradation of the oxide layer can expose interior Mo silicide to additional oxidation and the sequential process of oxidation and peeling can continue without offering oxidation protection for the alloy over long periods of exposure.

\section{Oxidation of $\mathrm{MoSi}_{2}-\mathrm{Si}_{3} \mathrm{~N}_{4}$ Composites}

Petrovic et al. [19] and Sadananda et al. [20] have been developing Mo-Si-based composites by fabricating materials like $\mathrm{MoSi}_{2}$ from various ceramic materials, such as $\mathrm{SiC}$, $\mathrm{Si}_{3} \mathrm{~N}_{4}, \mathrm{ZrO}_{2}, \mathrm{Al}_{2} \mathrm{O}_{3}, \mathrm{TiB}_{2}, \mathrm{TiC}$, etc. Table 2 lists the physical and thermal properties of $\mathrm{MoSi}_{2}$ and $\mathrm{Si}_{3} \mathrm{~N}_{4}$. Reinforcement of ceramic materials, e.g., with fibers, whiskers, and discrete particles in $\mathrm{MoSi}_{2}$, is directed toward improving the fracture toughness of the composite material. The room-temperature fracture toughness of monolithic $\mathrm{MoSi}_{2}$ is $\approx 3 \mathrm{Mpa} \cdot \mathrm{m}^{1 / 2}$ and that of equiaxed polycrystalline $\mathrm{Si}_{3} \mathrm{~N}_{4}$, densified without sintering additives, is also $3 \mathrm{MPa} \cdot \mathrm{m}^{1 / 2}[21,22]$. However, the room-temperature fracture toughness of $\mathrm{MoSi}_{2}$ matrix-Si $\mathrm{S}_{4}$-reinforced composite that contains $50 \mathrm{vol} . \% \mathrm{Si}_{3} \mathrm{~N}_{4}$ has been reported as $5.2 \mathrm{MPa} \cdot \mathrm{m}^{1 / 2}$. Furthermore, the fracture toughness of the composite of the same composition increases to 10 or $15 \mathrm{MPa} \cdot \mathrm{m}^{1 / 2}$ if the $\mathrm{Si}_{3} \mathrm{~N}_{4}$ grains are elongated $[23,24]$. Recently, a series of $\mathrm{MoSi}_{2}-\mathrm{Si}_{3} \mathrm{~N}_{4}$ composites were subjected to cyclic oxidation testing at $900^{\circ} \mathrm{C}$ for $55 \mathrm{~min}$, followed by a $5 \mathrm{~min}$ air cooling [25]. After 500 cycles, the material did not exhibit pesting degradation. However, based on the oxidation behavior of $\mathrm{MoSi}_{2}$ and $\mathrm{Si}_{3} \mathrm{~N}_{4}$, pesting or accelerated oxidation is not expected at $900^{\circ} \mathrm{C}$ and the purpose of the present work is to examine the oxidation behavior of $\mathrm{MoSi}_{2}-\mathrm{Si}_{3} \mathrm{~N}_{4}$ composites of various compositions (see Table 1 for details) at temperatures between 500 and $1400^{\circ} \mathrm{C}$. 
It is well known that $\mathrm{MoSi}_{2}$ undergoes pesting degradation at temperatures between 400 and $600^{\circ} \mathrm{C}$ and that a $\mathrm{SiO}_{2}$ scale, which protects the $\mathrm{MoSi}_{2}$ alloy from further oxidation forms above $\approx 900^{\circ} \mathrm{C}$ [10-13]. Pure $\mathrm{Si}_{3} \mathrm{~N}_{4}$ is resistant to oxidation in air over the wide temperature range of $500-1200^{\circ} \mathrm{C}$ [26]. Figure 14 shows weight change data for $\mathrm{Si}_{3} \mathrm{~N}_{4}$ material when exposed to air at $1200^{\circ} \mathrm{C}$. Even though the fracture toughness of the $\mathrm{MoSi}_{2}-\mathrm{Si}_{3} \mathrm{~N}_{4}$ composites, especially with elongated $\mathrm{Si}_{3} \mathrm{~N}_{4}$ grains, is promising, our knowledge of their oxidation behavior, especially at low temperatures is limited. Therefore, pure $\mathrm{MoSi}_{2}$ and specimens of. $\mathrm{MoSi}_{2}-\mathrm{Si}_{3} \mathrm{~N}_{4}$ composites that contained $20,40,60$, and $80 \mathrm{vol} . \% \mathrm{Si}_{3} \mathrm{~N}_{4}$ were oxidized in air at $500,800,1100$, and $1400^{\circ} \mathrm{C}$. Figure 15 shows the weight change data for several $\mathrm{MoSi}_{2}-\mathrm{Si}_{3} \mathrm{~N}_{4}$ composite compositions that were oxidized in air at the four temperatures. The results show that the composites are resistant to oxidation at 800,1100 , and $1400^{\circ} \mathrm{C}$. Interestingly, the oxidation rates of the composites are lower by more than an order of magnitude than rates observed for the Ames, LANL, and ORNL alloys tested in the present study (compare data in Figs. 4, 11, and 15). But, significant increase in weight loss is noted at $500^{\circ} \mathrm{C}$, the regime of pesting or nonprotective oxidation for $\mathrm{MoSi}_{2}$. The results also indicate more rapid oxidation at $500^{\circ} \mathrm{C}$ for composites with 60 or 80 vol.\% $\mathrm{Si}_{3} \mathrm{~N}_{4}$ than for the other compositions. Additional work is needed in 500 $800^{\circ} \mathrm{C}$ range to evaluate the severity of composite degradation that is due to oxidation. Another issue with these composites that is not evident in the oxidation data is the presence or lack of stability of the surface layers in the oxidized specimens. Figure 16 shows the SEM photomicrographs of the surfaces of $\mathrm{MoSi}_{2}-\mathrm{Si}_{3} \mathrm{~N}_{4}$ composites after a 100 -h oxidation at $1400^{\circ} \mathrm{C}$. The protective layer on the surface exhibits significant cracking and peeling but no spalling, indicating that its adherence is adequate but that it is mechanically weak. The cracking and peeling behavior of the composites are similar to those observed in B-containing $\mathrm{Mo}_{5} \mathrm{Si}_{3}$ (see photomicrographs marked 1000 and $1200^{\circ} \mathrm{C}$ in Fig. 13), indicating that the development of scale is dictated by the $\mathrm{MoSi}_{2}$ in the composite, whereas $\mathrm{Si}_{3} \mathrm{~N}_{4}$ contributes little to the oxidation protection of the composite.

Figure 17 shows SEM photomicrographs of the cross sections of the specimens shown in Fig. 16. The scales appeared glossy and in specimens with 0,20 , and $40 \mathrm{vol} . \% \mathrm{Si}_{3} \mathrm{~N}_{4}$, the scales seem to have melted during the 100 -h exposure. The thickness of the scale was $\approx 60-100 \mu \mathrm{m}$. The light-colored phase in the outer region and in the interior of the scale is the sintering aid, e.g., $\mathrm{Y}_{2} \mathrm{O}_{3}$, used in the fabrication of the composite. The composite with 80 vol.\% $\mathrm{Si}_{3} \mathrm{~N}_{4}$ exhibited a continuous, thin $(\approx 5 \mu \mathrm{m})$ silica scale; but, the scale showed several transverse cracks, indicating that its plasticity may be less than that observed in composites that contained a lower vol.\% of $\mathrm{Si}_{3} \mathrm{~N}_{4}$. The results, obtained thus far, seem to suggest that the oxidation performance of 
the composite material will be largely determined largely by the oxidation behavior of the Mo silicide in the composite.

\section{SUMMARY}

Binary Mo silicides are prone to nonprotective oxidation at low temperatures $\left(500-700^{\circ} \mathrm{C}\right)$ in air, primarily because silica growth rates to form an external continuous scale are extremely low. Additions of more stable oxide-forming elements may only have a marginal benefit at low temperatures because the growth rates of most of those oxides are also low. Addition of $\mathrm{B}$ to accelerate formation of borosilicate at low temperatures is not proved. Silica (or borosilicate) scale seems to peel at elevated temperatures $\left(1000-1400^{\circ} \mathrm{C}\right)$, indicating significant plasticity; however, long-term protective capacity of the scale may be degraded. The oxidation behavior of silicide-ceramic composites (e.g., $\mathrm{MoSi}_{2}-\mathrm{Si}_{3} \mathrm{~N}_{4}$ ) is excellent in the temperature range of 800$1400^{\circ} \mathrm{C}$ and the rates for the composites are significantly lower than those observed for Bcontaining $\mathrm{Mo}_{5} \mathrm{Si}_{3}$ alloys. Even the composites exhibit pesting or nonprotective scaling at lower temperature (e.g., $500^{\circ} \mathrm{C}$ ) suggesting that the ceramic component is inert from the oxidation standpoint and the oxidation resistance of the composite is determined predominantly by that of the silicide in the composite.

\section{ACKNOWLEDGMENTS}

This work was supported the U.S. Department of Energy, Office of Fossil Energy, Advanced Research \& Technology Program, Office of Energy Research, Basic Energy Sciences, Division of Materials, and Philip Morris, USA. The authors thank A. Thom from Ames Laboratory, F. Chu from LANL, and J. Schneibel from ORNL for supplying various specimens and helpful discussions during the course of this work. D. L. Rink assisted with oxidation experiments and SEM/EDX analysis of oxidized specimens. P. Johnson analyzed the oxidized specimens by XRD.

\section{REFERENCES}

1. R. M. Aiken Jr., Scr. Metall. Mater. 26, 1025-30, 1992.

2. A. K. Vasudevan, J. J. Petrovic, Mater. Sci. Eng. A155, 1, 1992.

3. G. Sauthoff, Z. Metallkd., 77, 554-566, 1986.

4. K. J. Bowman, "Refractory Metal Disilicide Research," P. D. Desai, ed., MIAC Report 2, West Lafayette, IN, p. 9, 1992.

5. C. D. Wirkus, D. R. Wilder, J. Am. Ceram. Soc., 49, 173-177, 1966.

6. R. E. Regan, W. A. Baginski, C. A. Krier, Ceram. Bull., 46, 502-509, 1967. 
7. D. A. Berztiss, R. R. Cherchiara, E. A. Gulbransen, F. S. Pettit, G. H. Meier, Mater. Sci. Eng., A155. 165, 1992.

8. R. W. Bartlett, J. W. McCamont, P. R. Gage, J. Amer. Ceram. Soc., 48, 551, 1965.

9. S. Bose, Mater. Sci. Eng., A155, 217-225, 1992.

10. E. Fitzer, Proc. Of $2^{\text {nd }}$ Plansee Seminar, Reutte/Tyrol, Pergamon Press, Oxford, p. 56, 1956.

11. J. Berkowitz-Mattuck, P. E. Blackburn, E. J. Felten, Trans. TMS-AIME, 233, 1093, 1965.

12. J. Berkowitz-Mattuck, M. Rossetti, D. W. Lee, Met. Trans. 1, 479, 1970.

13. P. J. Meschter, Metall. Trans. A, 23A, 1763-72, 1992.

14. T. Maruyama, K. Yanagihara, K. Nagata, Corros. Sci. 35, 939, 1993.

15. K. Yanagihara, T. Maruyama, K. Nagata, Mater. Trans. Jpn. Inst. Met. 34, 1200, 1993.

16. K. Yanagihara, T. Maruyama, K. Nagata, Intermetallics, 3, 243, 1995.

17. T. Maruyama, K. Yanagihara, Mater. Sci. and Eng., A239-240, 828, 1997.

18. M. Meyer, M. Akinc, J. Amer. Ceram. Soc. 79, 938, 1996.

19. J. J. Petrovic, A. K. Vasudevan, Intermetallic Matrix Composites II, D. B. Miracle, D. L. Anton, and J. A. Graves, eds., Materials Research Soc., Pittsburgh, p. 229, 1993.

20. K. Sadananda, C. R. Feng, R. Mitra, and S. C. Deevi, Mater. Sci. Eng., A261, 223, 1999.

21. R. K. Wade, J. J. Petrovic, J. Amer. Ceram. Soc., 75, 1682, 1992.

22. I. Tanaka, G. Pezzotti, T. Okamoto, and Y. Miyamoto, J. Amer. Ceram. Soc., 72, 1656, 1989.

23. M. G. Hebsur, Mater. Sci. Eng., A261, 24, 1999.

24. S. C. Deevi and K. Sadananda, to be published in Intermetallics, 2000.

25. R. K. Kowalik, M. G. Hebsur, Mater. Sci. Eng., A261, 300, 1999.

26. K. Natesan, CORROSION 97, Paper 143, NACE International, Houston, 1997. 


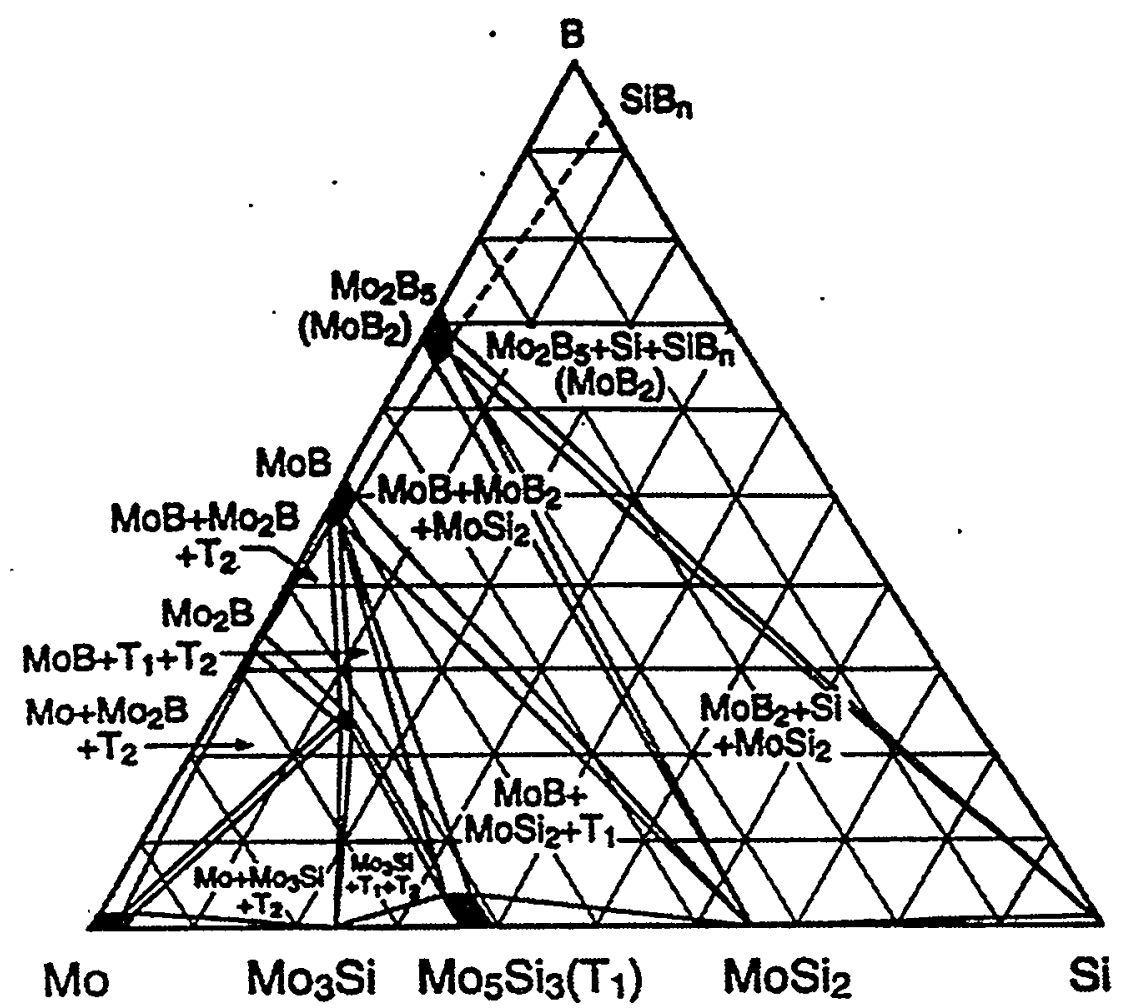

Fig. 1. Schematic illustration of Mo-Si-B ternary-phase diagram, showing thermodynamic stability of various phases.

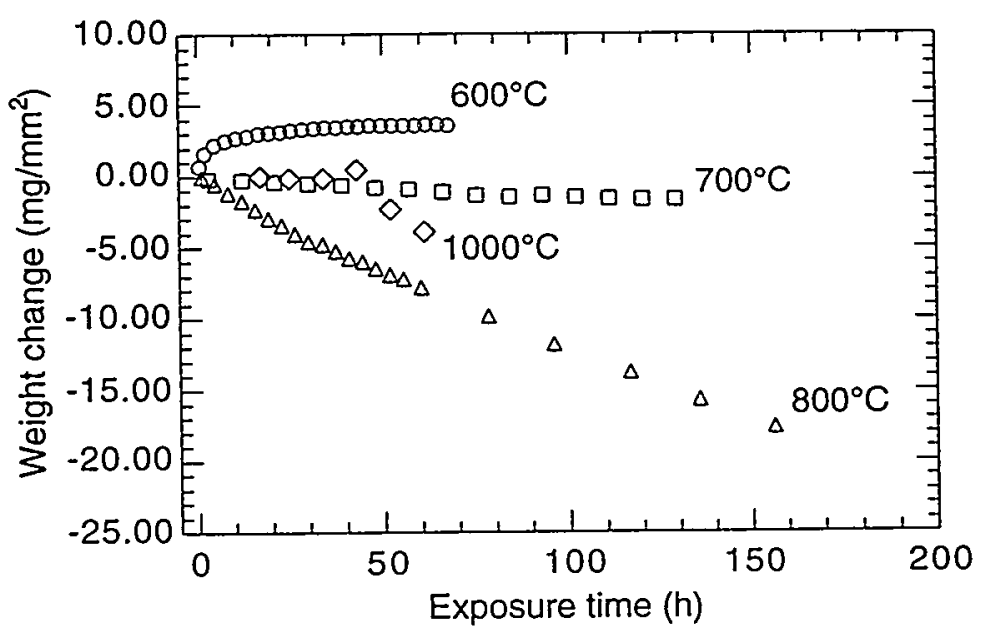

Fig. 2. Thermogravimetric weight change data for oxidation of $\mathrm{Mo}_{5} \mathrm{Si}_{3}$ in air at several temperatures. 


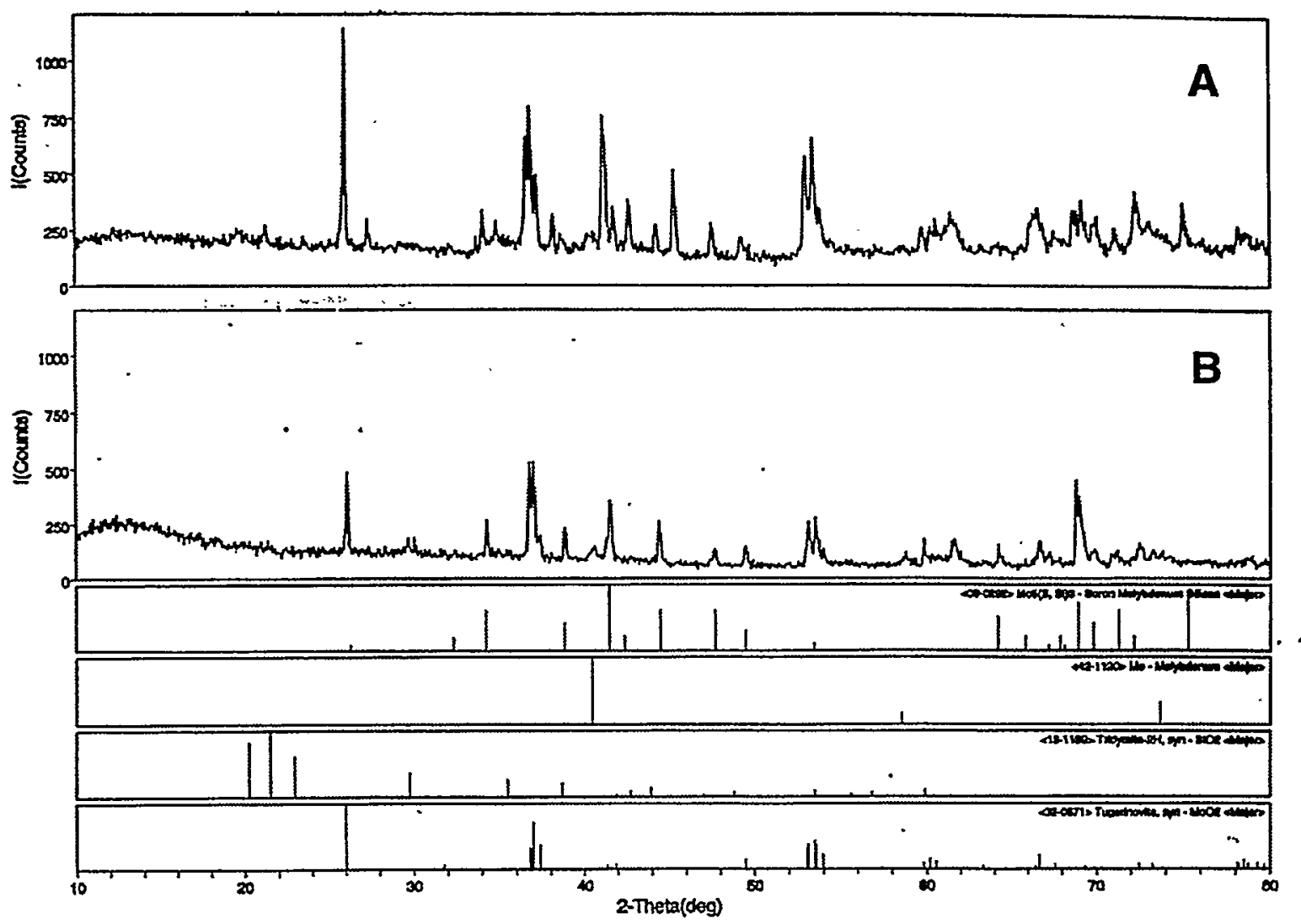

Fig. 5. XRD patterns for (a) Ames alloy and (b) LANL-T2 alloy, after oxidation in air at: $800^{\circ} \mathrm{C}$.

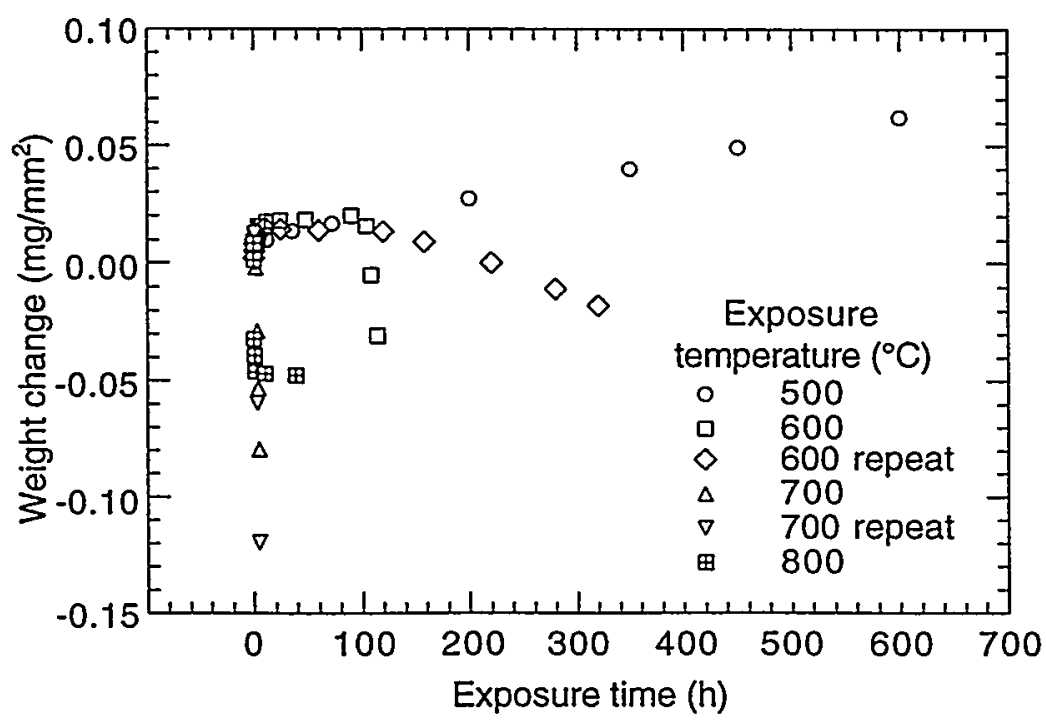

Fig. 6. Thermogravimetric weight change data for Ames alloy oxidized at $500,600,700$, and $800^{\circ} \mathrm{C}$ 

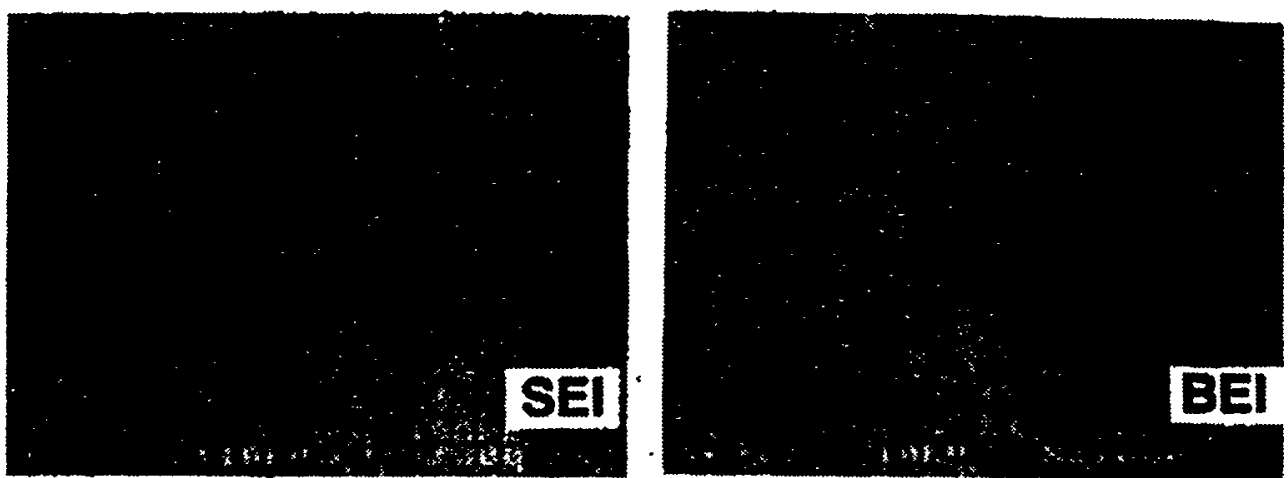

Fig. 7. SEM secondray- and backscattered-electron images of the Ames alloy after oxidation in air at $600^{\circ} \mathrm{C}$.

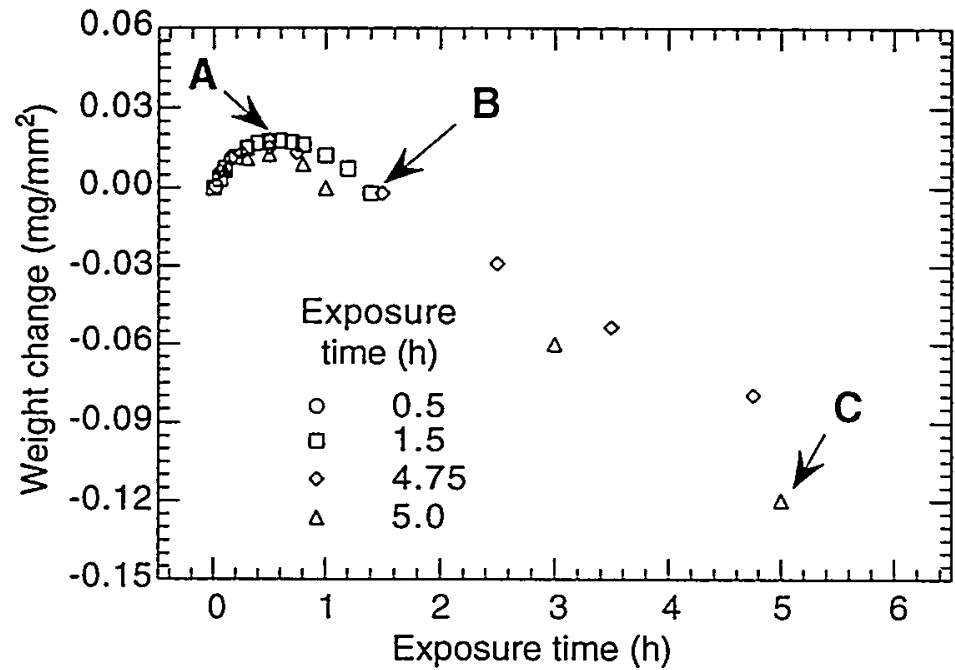

Fig. 8. Thermogravimetric weight change data for the Ames alloy oxidized for several time periods at $700^{\circ} \mathrm{C}$. $\mathrm{A}, \mathrm{B}$, and $\mathrm{C}$ mark exposure times of $0.5,1.5$, and $5 \mathrm{~h}$. 


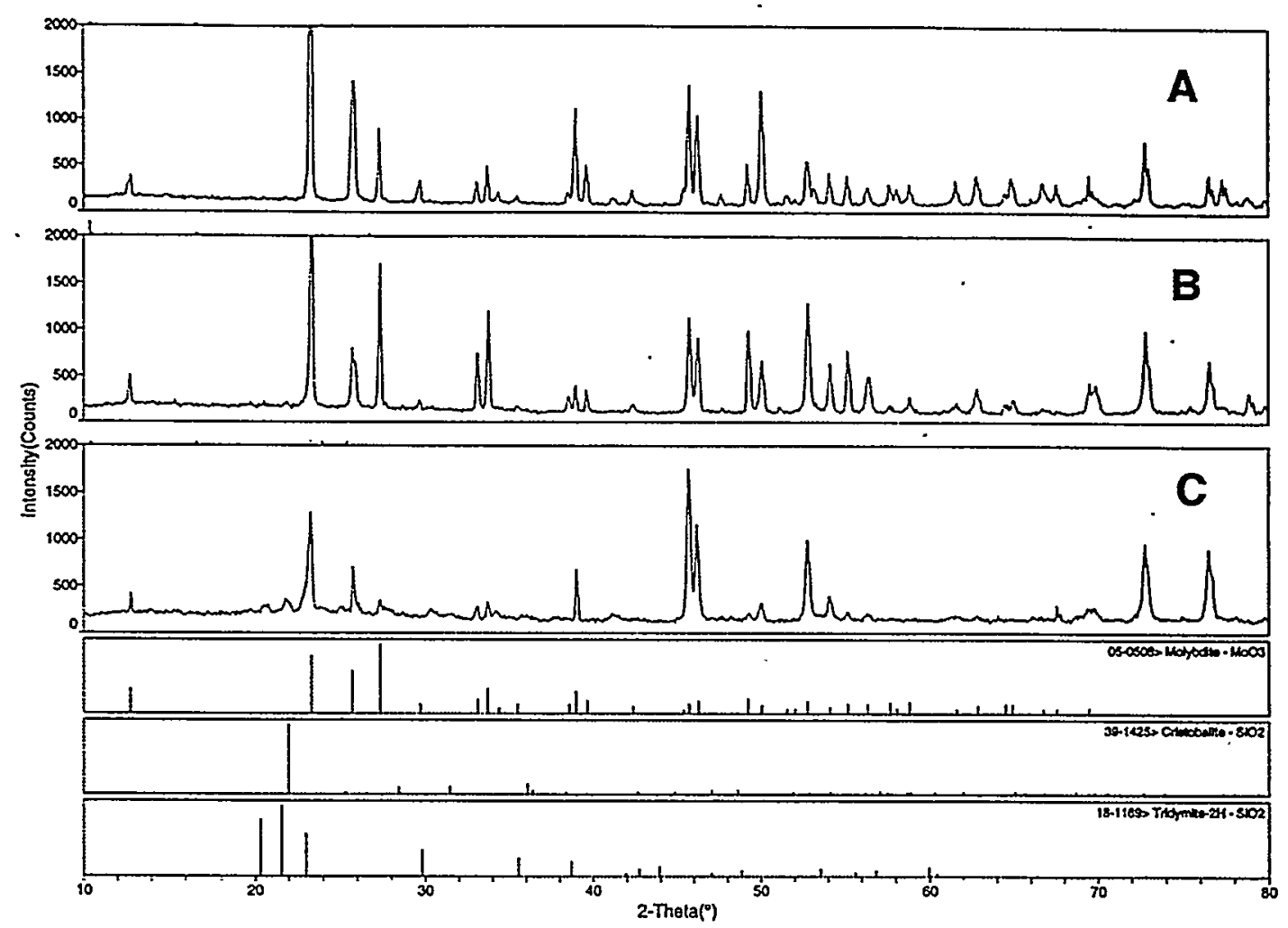

Fig. 9. XRD patterns for Ames alloy oxidized at $700^{\circ} \mathrm{C}$ in air for (A) 0.5 , (B) 1.5 , and (C) $5 \mathrm{~h}$.
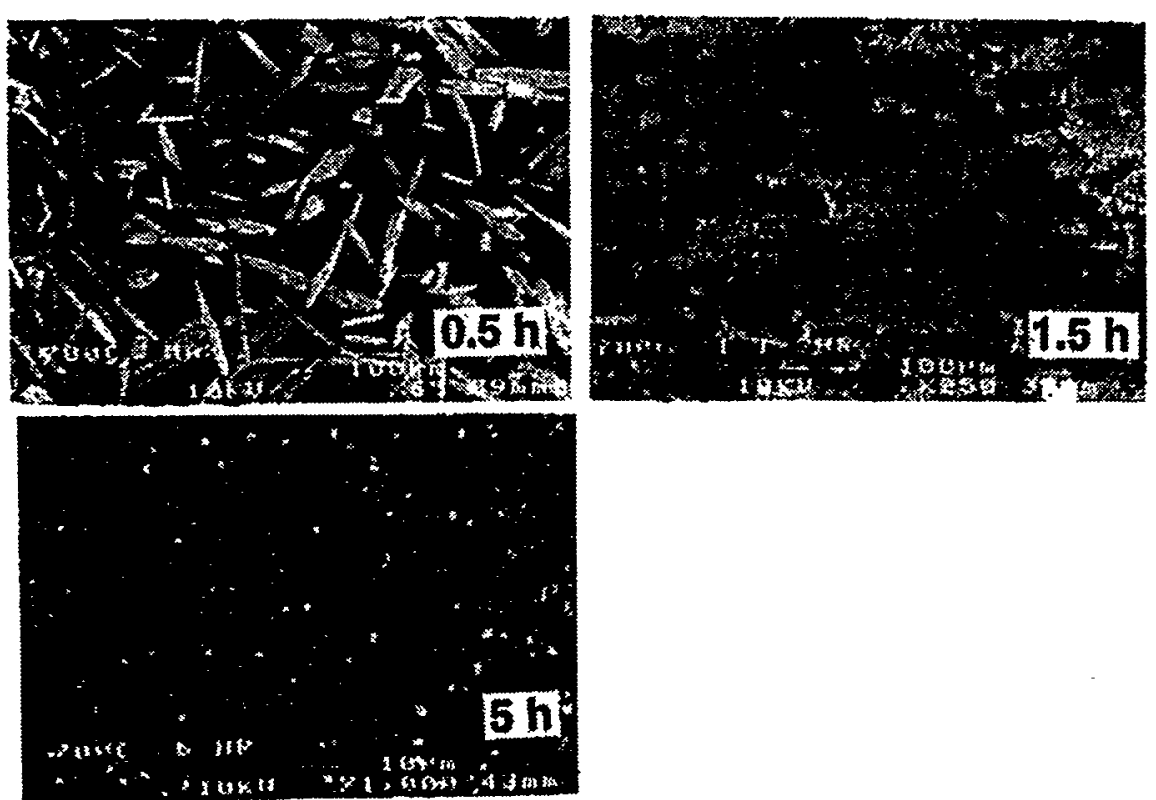

Fig. 10. SEM photomicrographs of Ames alloy after oxidation in air at $700^{\circ} \mathrm{C}$ for $0.5,1.5$, and $5 \mathrm{~h}$. 


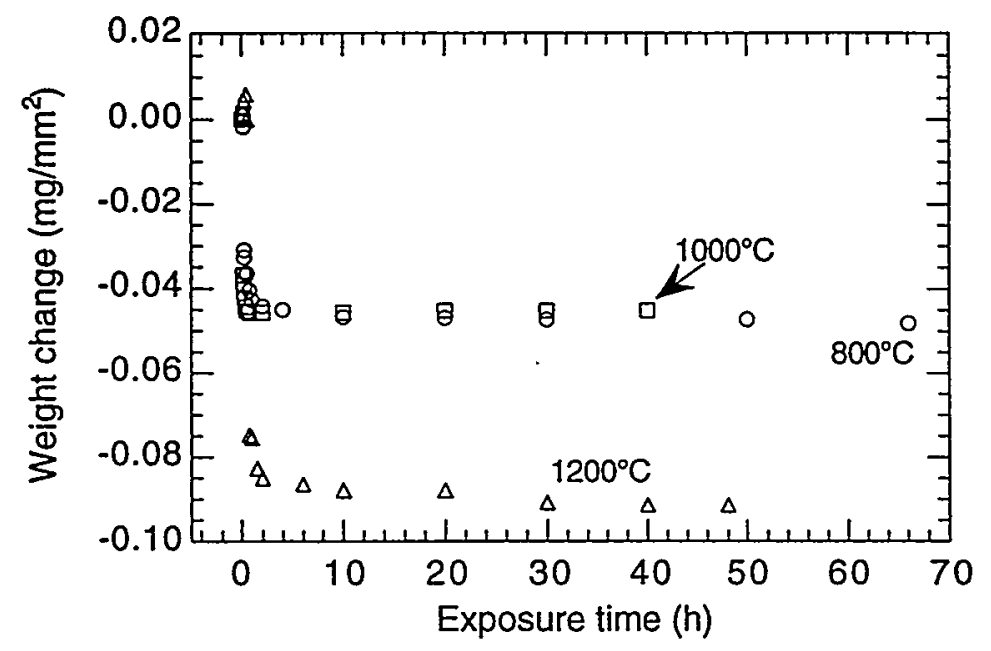

Fig. 11. Thermogravimetric weight change data for Ames alloy oxidized at 800,1000 , and $1200^{\circ} \mathrm{C}$.

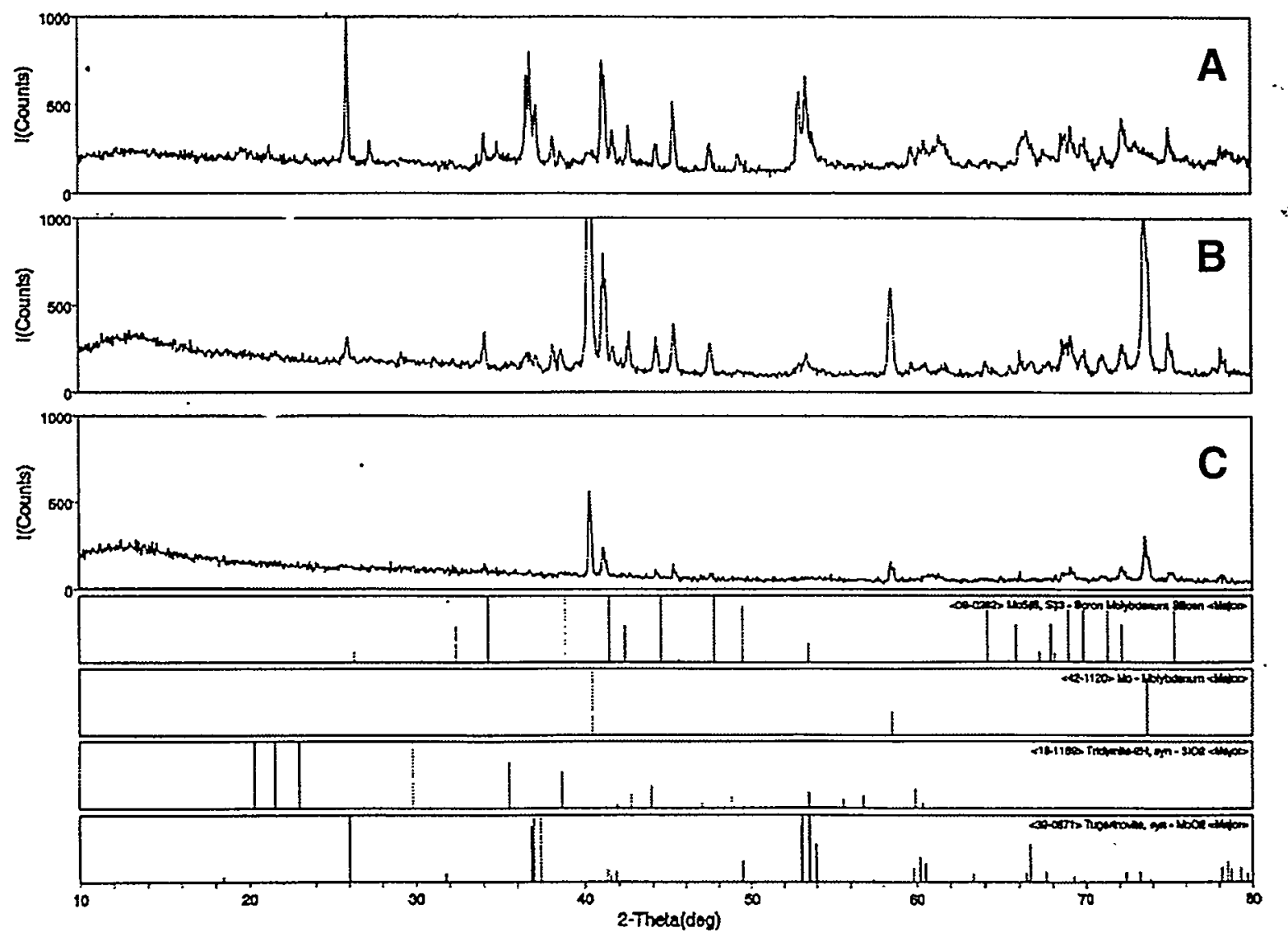

Fig. 12. XRD patterns for Ames alloy oxidized in air at (A) 800 , (B) 1000 , and (C) $1200^{\circ} \mathrm{C}$. 

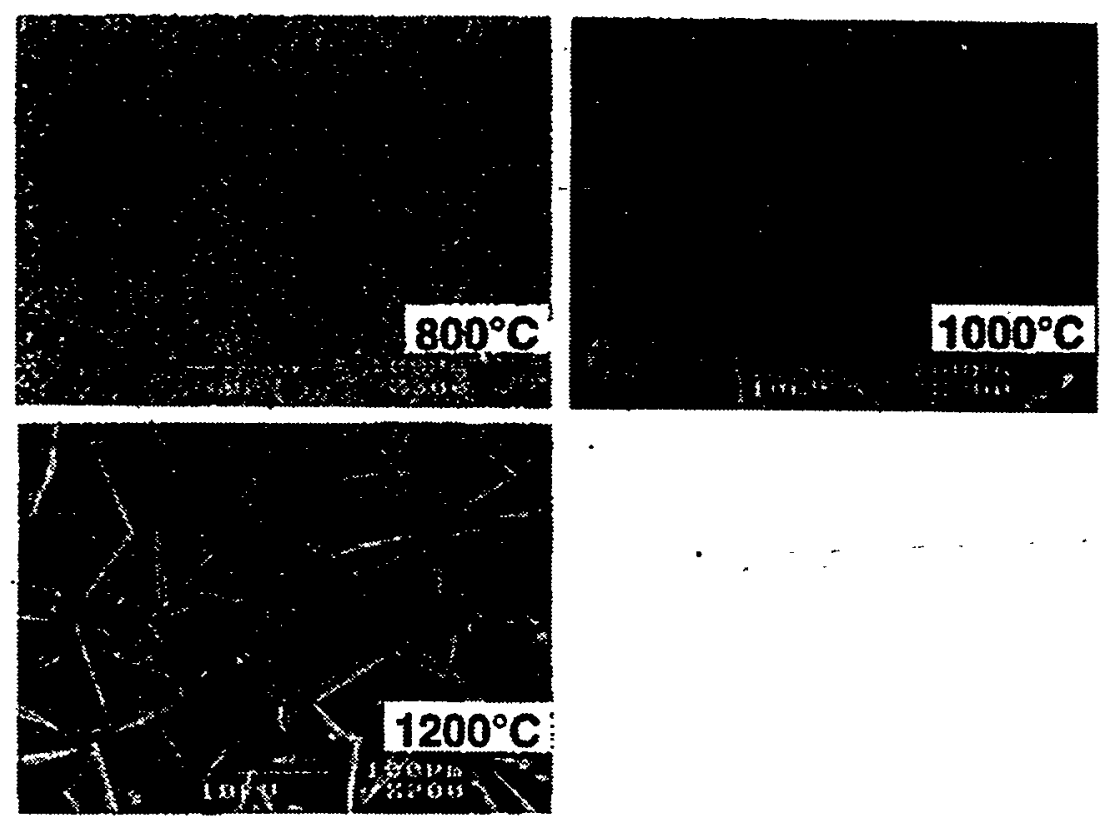

Fig. 13. SEM photomicrographs of Ames alloy after oxidation in air at 800,1000 , and $1200^{\circ} \mathrm{C}$.

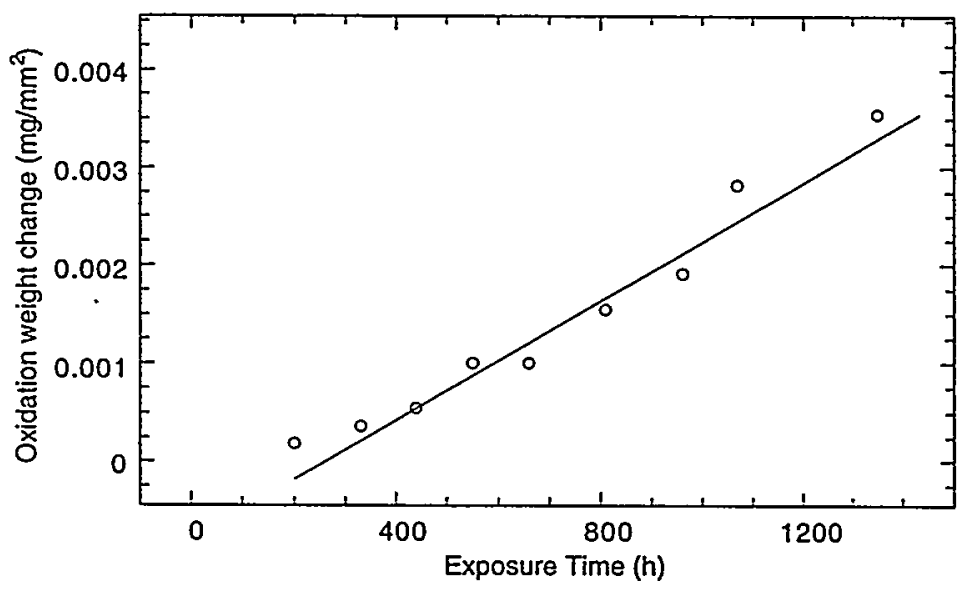

Fig. 14. Weight change data for oxidation of $\mathrm{Si}_{3} \mathrm{~N}_{4}$ in air at $1200^{\circ} \mathrm{C}$. 


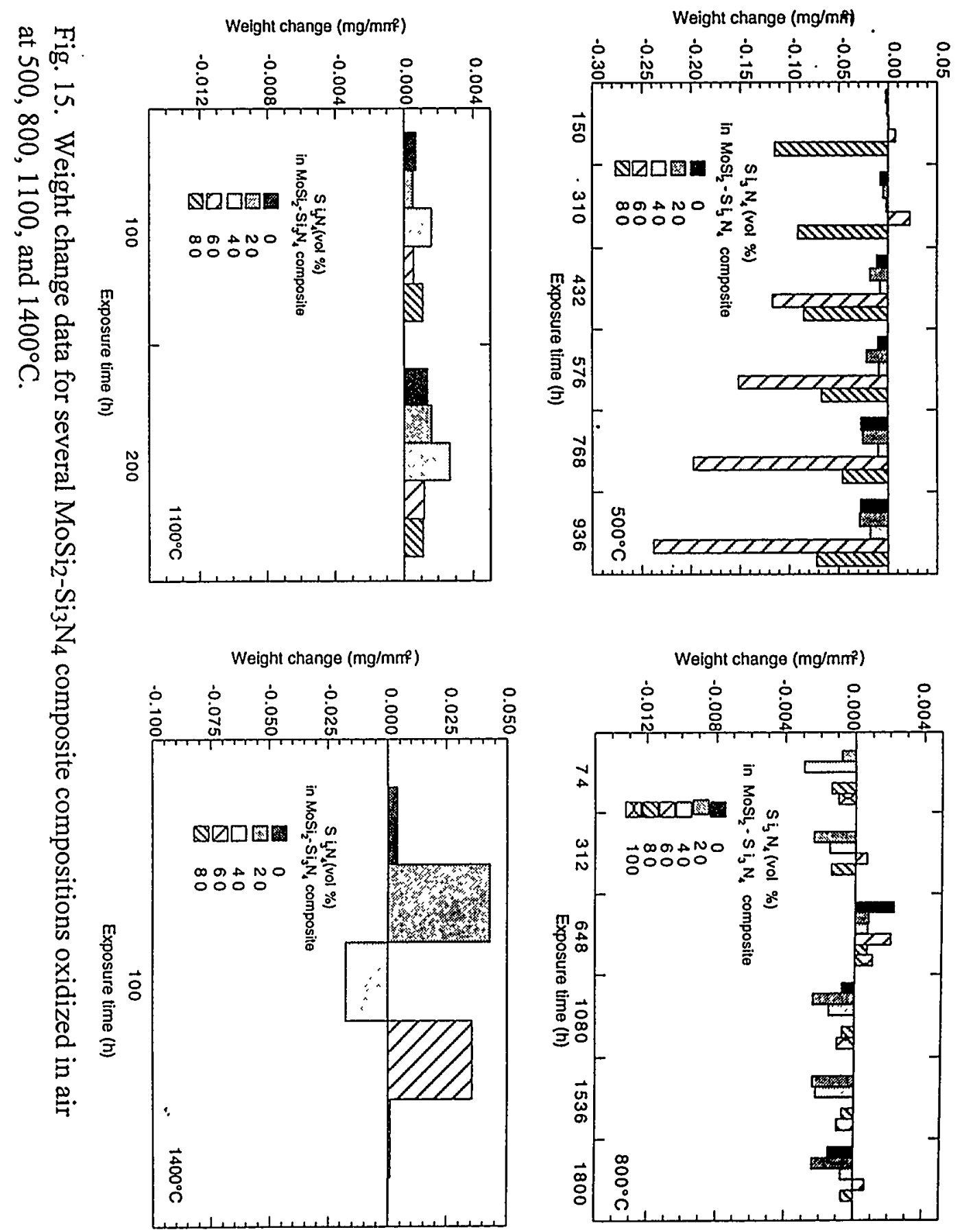



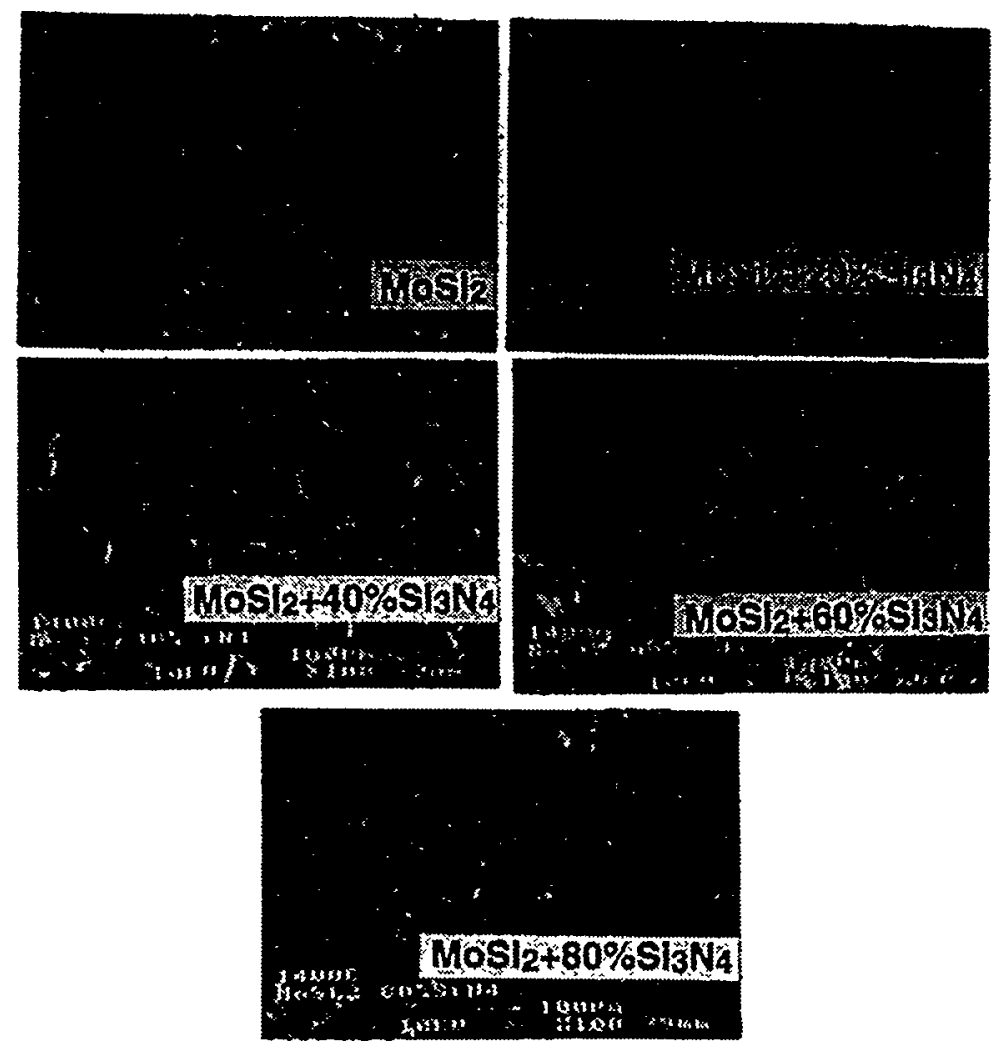

Fig. 16. SEM photomicrographs of surfaces of several $\mathrm{MoSi}_{2}-\mathrm{Si}_{3} \mathrm{~N}_{4}$ composite specimens after 100 -h oxidation in air at $1400^{\circ} \mathrm{C}$ 

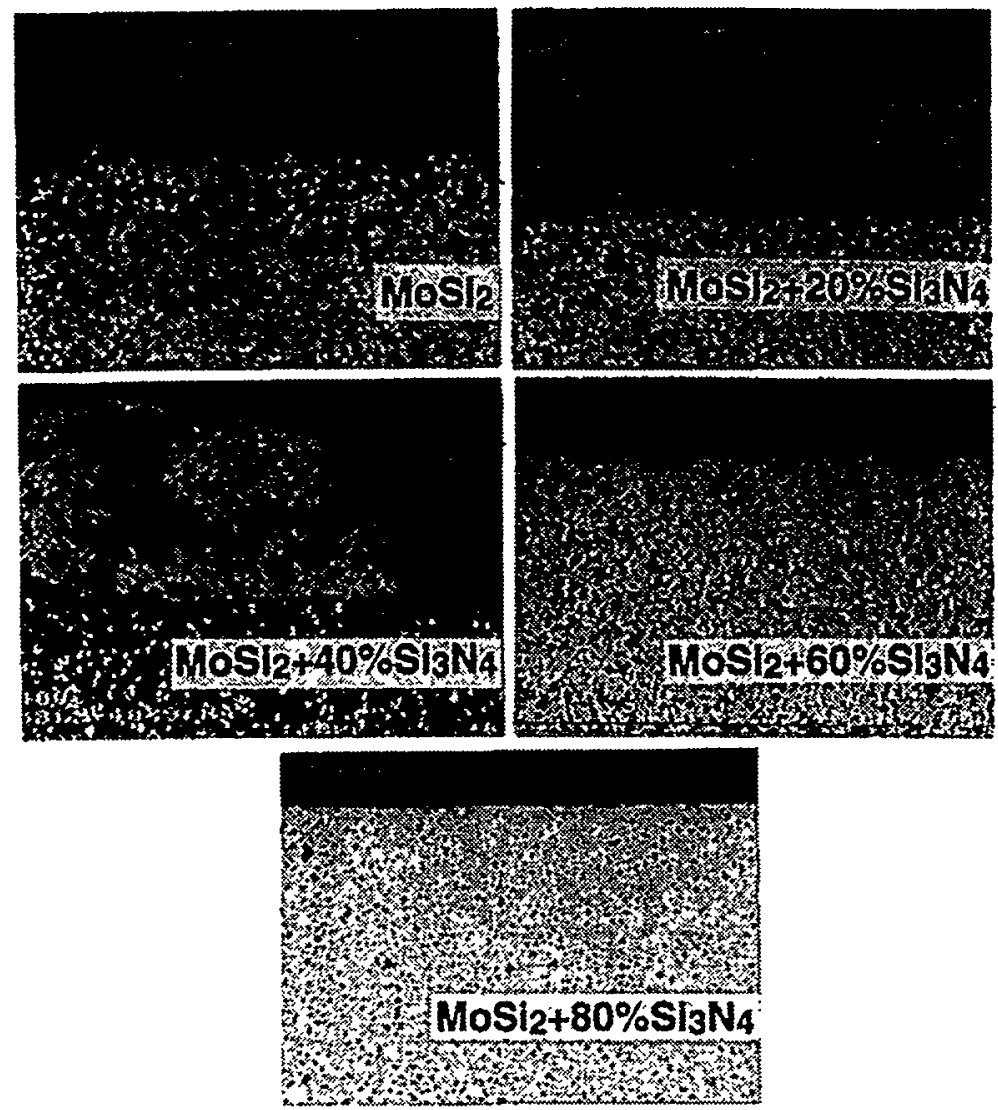

Fig. 17. SEM photomicrographs of cross sections of several $\mathrm{MoSi}_{2}-\mathrm{Si}_{3} \mathrm{~N}_{4}$ composite specimens after 100 -h oxidation in air at $1400^{\circ} \mathrm{C}$ 